\title{
Site Index and Volume Growth Percentage Determination for Privately Owned Uneven-aged Stands of Quercus pubescens and Quercus ilex along the Croatian Adriatic Coast
}

\author{
Alen Berta ${ }^{1 *}$, Tom Levanič ${ }^{2}$, Denis Stojsavljević ${ }^{3}$, Vladimir Kušan ${ }^{1}$
}

(1) Oikon Ltd. - Institute of Applied Ecology, Trg senjskih uskoka 1-2, HR-10020 Zagreb, Croatia; (2) Slovenian Forestry Institute, Večna pot 2, SI-1000 Ljubljana, Slovenia; (3) Pro Silva Ltd., Trg senjskih uskoka 1-2, HR-10020 Zagreb, Croatia

*Correspondence: e-mail: alenberta@gmail.com

\begin{abstract}
Citation: BERTA A, LEVANIČ T, STOJSAVLUEVIĆ D, KUŠAN V 2019 Site Index and Volume Growth Percentage Determination for Privately Owned Uneven-aged Stands of Quercus pubescens and Quercus ilex along the Croatian Adriatic Coast. Southeast Eur for 10 (1): 65-75. DOI: https://doi. org/10.15177/seefor.19-08

Received: 8 Mar 2019; Revised: 7 May 2019; Accepted: 13 May 2019; Published online: 7 June 2019
\end{abstract}

\begin{abstract}
Background and purpose: Although organized forestry has existed in Croatia for more than 250 years, this mostly entailed state forests. During the last decade, Extension Services have started to support the development of forest management plans for privately owned forests. Lately, FMPs have been developed for nearly 3/4 of privately owned forests in Croatia. During the creation of those plans, yield tables and normal models for state-owned forests, primarily even-aged stands with long-time management, were used because similar data was not developed for uneven-aged and poorly managed forests. This research encompasses privately owned forests in the Croatian Mediterranean and sub-Mediterranean regions where holm oak (Quercus ilex L.) and downy oak (Quercus pubescens Willd.) are the prevailing species in forest stands. The main goal was to determine site indices revealed in the analysis of yearly radial increments and to create relevant yield tables. Materials and Methods: In this study, 1286 oak trees were cored to the centre on 377 locations spread in privately owned forests in Croatian Mediterranean and sub-Mediterranean regions. The ratio of trees and locations was approximately 3:1 for Q. pubescens. Some cored trees were more than two centuries old. After the standard sample preparation for dendrochronological analysis, cores were scanned, and tree-ring widths were determined. In total, ring width for over 67,000 rings was determined and measured.

Results: Based on the data dispersion of cumulative tree increments at 40 years of age, 2 site index classes for $Q$. ilex and 3 for $Q$. pubescens were created based on $k$-means clustering. Prodan's growth function was fitted to the created clusters to determine the site's "model" tree. For the model trees, the percentage of volume growth was calculated. For easier field site index determination, height curves based on field data for each site index were calculated.

Conclusions: For the first time in Croatia, systematic and controlled data on the growth (and age) of uneven-aged privately owned forests in the Croatian Mediterranean and sub-Mediterranean area were collected. Based on the data collected in the field, three different site indices for downy oak and two site indices for holm oak were determined. These results could find their application during operational forest management and forest exploitation because they allow for more accurate determination of the site production strength in the explored stands.
\end{abstract}

Keywords: privately owned forests, dendrochronology, uneven-aged forests, site productivity, site index 


\section{INTRODUCTION}

More than a half of the Croatian Mediterranean and sub-Mediterranean area - circa 800,000 ha - are covered with forest vegetation, and more than $95 \%$ of it consists of holm oak (Quercus ilex L.) or downy oak (Quercus pubescens Willd.) forests, mainly in degraded forms (coppice or shrubs/ maquis).

In the study of Gea-Izquierdo et al. [1] it is stated that Quercus sp. is a widespread genus in the Northern Hemisphere, and that it is the most important broadleaf genus in the Mediterranean region. The most widespread evergreen oak species in the West Mediterranean region is holm oak. Its distribution ranges in latitude from Southern France to the Anti-Atlas in Morocco [2]. In Croatia, Mediterranean climate only affects islands and the narrow area on the coastline. Larger proportion of coastal area is influenced by sub-Mediterranean climate, where downy oak prevails. Downy oak has a wide areal distribution that extends from the north-east of the Iberian Peninsula to Asia Minor. Downy oak, together with pedunculate oak and sessile oak is the most common oak species in Central Europe [3].

Regarding ownership, half of those forests are private properties. Although organized forestry has existed in Croatia for more than 250 years, it mostly entailed state forests. Privately owned forests were not actively managed in the past although they had to adhere to certain laws and regulations throughout history, but forest owners had a possibility to decide what and when to do with their ownership. This led to uneven-aged forests with great diversity of stand structure in small areas. This is reflected in the small size of forest plots and the presence of multiple owners on one plot, making sustainable management impossible. The average private forest plot in these areas is 0.27-0.37 ha, with forest estates ranging from 1.73 to 2.43 ha, in many cases having several owners [4].

Čavlović [5] stated that there are multiple challenges for private forest owners: small area management, heterogeneity of stands, low quality of cadaster and land registry, unmarked cadastral plot borders and forest degradation.

After the WWII, some Forest Management Plans (FMP) for privately owned forests were created, but they encompassed only a few percentages of privately owned forests. For many of these areas, FMP were created up to the 1990s.

During the last decade, Extension Services have started to systematically support the development of forest management plans for privately owned forests. Currently, FMPs have been developed for nearly $3 / 4$ of privately owned forests in Croatia. For the aforementioned plans, growth tables and normal models for state-owned forests, primarily even-aged stands with long-time management, were used because similar data has never been developed for uneven-aged and poorly managed forests.

Due to the presence of double ring or absent ring and its high wood density (compared to other European species), holm oak is not a widely researched species. Additionally, holm oak is an evergreen tree species, which means that it can potentially grow during the whole year, which could lead to problems related to tree-ring boundary recognition and calls to special attention when measuring tree-ring widths. Previously conducted research was oriented more towards dendrochronology and dendroecology and correlation between climate and tree-ring width than towards radial increment investigation [1, 2, 6-8]. The only research known to the authors and comparable to this one was study of GeaIzquierdo et al. [9].

Gea-Izquierdo et al. [1] also stated that holm oak, due to its wide distribution, confers great potential for dendroecology upon the species if tree rings can be correctly dated despite the presence of double and absent rings (e.g. $[6,10,11])$ or unclear tree-ring boundaries.

Downy oak has been more studied than holm oak, but not in a comparable manner. Previous papers focused on the influence of climate or environment on the growth in specific years $[12,13]$ or on 10-year average increment [14].

With this research, for the first time, privately owned forests have been encompassed in the Croatian Mediterranean and sub-Mediterranean region where holm oak (Quercus ilex L.) and downy oak (Quercus pubescens Wild.) forests are the most common forest species by coverage. The main goal was to determine site indices revealed in the analysis of yearly radial increments and to model volume percentage increment of the mean basal area of trees for those site indices.

\section{MATERIALS AND METHODS}

\section{General Description of the Locations}

The object of this research were privately owned forests in Croatian Mediterranean and sub-Mediterranean regions. These forest areas are covered mainly by holm oak (Quercus ilex L.) or downy oak (Quercus pubescens Willd.) forests, respectively (Figure 1 ).

By comparing these areas with CORINE land cover database for Croatia (CAEN) for reference year 2012 (categories encompassing forests and forest succession codes 311, 312, 313, 323 and 324) and the coverage of the state-owned forests (Croatian Forests Ltd.), it was assumed that there are approximately 400,000 privately owned forests in Croatian Mediterranean and sub-Mediterranean regions (Figure 2).

In 2007, Extension Services started to systematically create forest management plans (FMPs) for privately owned forests, many of which were created for the first time. By the time of this project's establishment, FMPs have been created for almost half of the research area (Figure 3).

Data from FPMs are the only valid reference data for privately owned forest areas and management classes; therefore, only forest compartments in these management units where management classes consisted of holm oak or downy oak (coppice or high forests) were selected. In each compartment, 2-4 locations were selected, covering as many diverse forest stand characteristics as possible from FMPs (DBH, stand volume, elevation, slope, etc.), while 


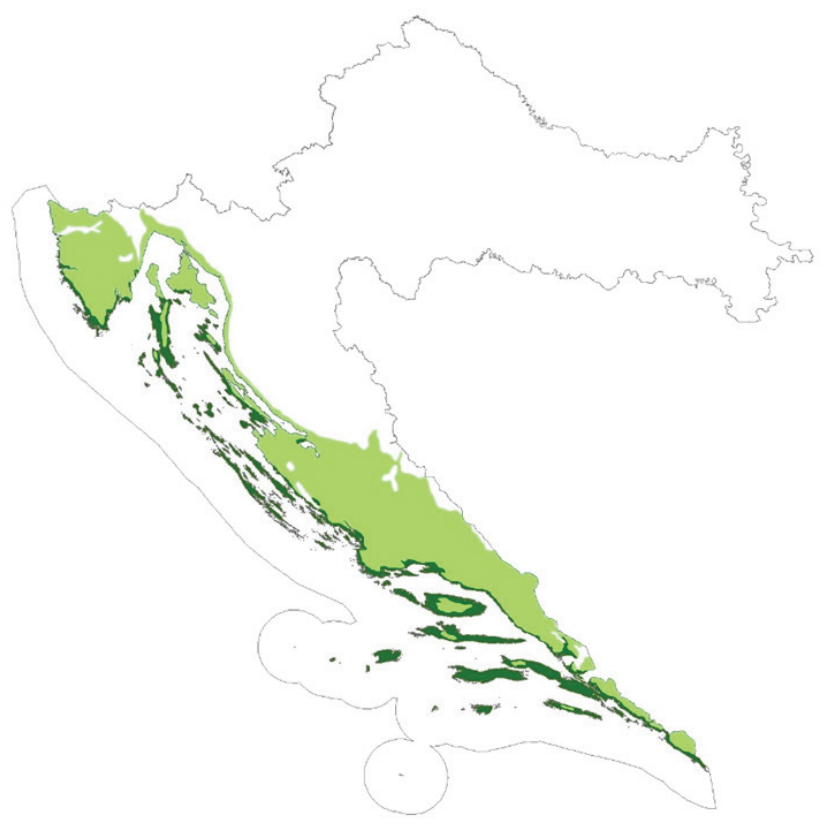

FIGURE 1. Ecological areas of holm oak (dark green) and downy oak (light green) phytocenosis.

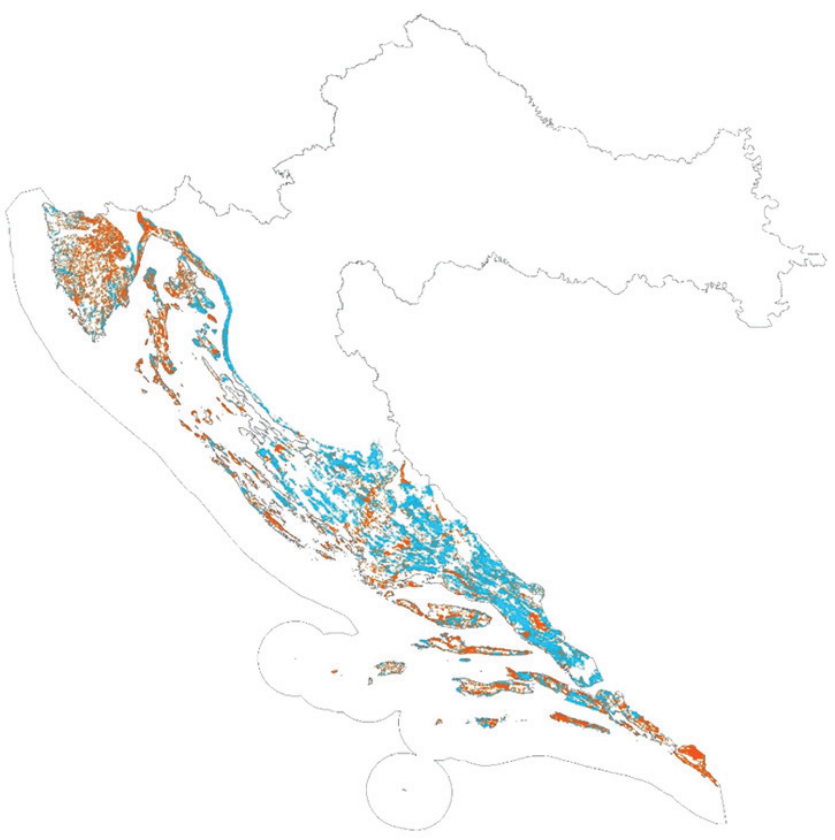

FIGURE 2. Areas of forests and forest succession by CLC 2012 and their ownership (blue - state-owned forests, red - privately owned forests). 


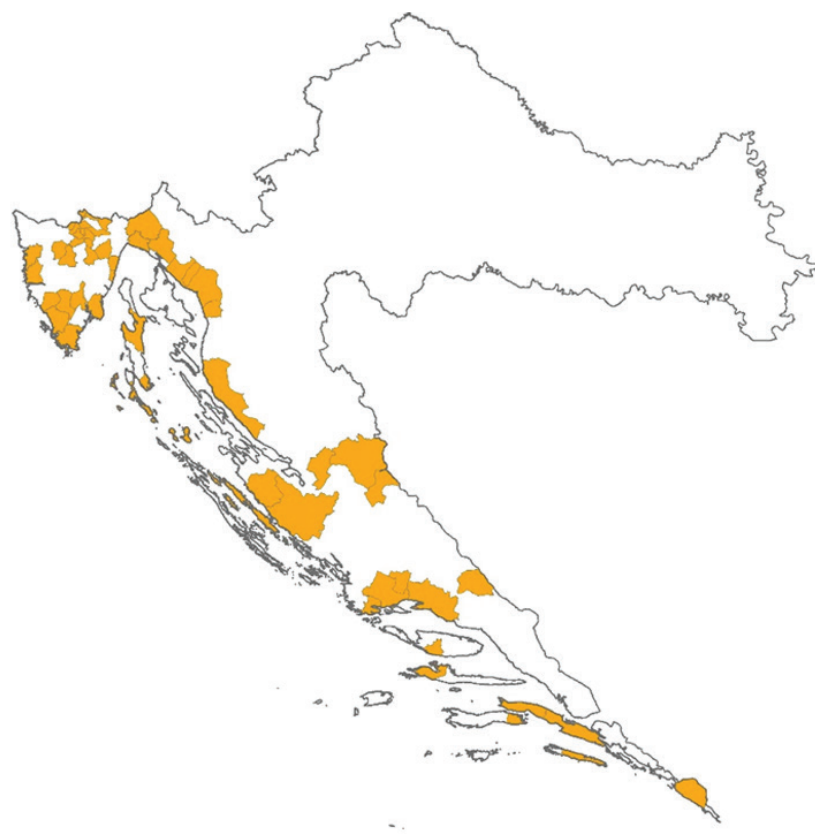

FIGURE 3. Created FMPs in the researched area.

also trying to cover most of the research area. In total, 377 locations along the Croatian coast were selected (Table 1, Figure 4).

\section{Sampling Strategy}

On each plot 2-3 trees whose diameter corresponds to the mean basal area at the plot were sampled. Additionally, samples were taken from one dominant tree at the plot. From each sampled tree 2 cores per tree or one core through the tree were taken, or in some cases, stem disks were acquired as well. During a field campaign 994 Quercus pubescens (QUPU) and 308 Quercus ilex (QUIL) trees were sampled.

\section{Sample Processing and Measurement}

The samples were prepared in the laboratory according to the standard dendrochronological procedure [15]. The samples were dried and dry cores were then fixed into wooden holders (which was not the case with the stem discs). Finally, they were sanded on an industrial belt sander with sanding paper of progressively higher grade - 120, 240 and 360 and, if necessary, with 400 or 600 grade to achieve good visibility of tree-rings.

All samples were scanned using a high-resolution flatbed scanner and tree-rings were measured with CDendro and CooRecorder software. Measured tree-ring width sequences were converted to TUCSON decadal format and imported into COFECHA [16] program for quality control. COFECHA programme checked for measuring errors and cross-dating mistakes. If errors in the tree-ring width sequences were detected, it was checked (1) if all tree-ring boundaries were correctly detected, and (2) if tree-rings in question were correctly measured. A small number of measurements needed to be corrected because of wrongly dated year beneath the bark or wrong calibration in the CDendro software. Corrected measurements were then re-imported into the main database.

For further processing tree-ring width sequences were exported to R programming environment [17] and processed to get a file which could be used for the calculation of site productivity.

TABLE 1. Share of plots by region and tree species.

\begin{tabular}{cccc} 
& \multicolumn{2}{c}{ Number of plots } & \multicolumn{2}{c}{ Total } \\
\cline { 2 - 3 } Region & Quercus pubescens & $\begin{array}{c}\text { Quercus } \\
\text { ilex }\end{array}$ & \\
\hline Istria and Kvarner & 210 & 75 & 285 \\
Northern and Central Dalmatia & 53 & 4 & 57 \\
Southern Dalmatia & 22 & 13 & 35 \\
Total & 285 & 92 & 377 \\
\hline
\end{tabular}




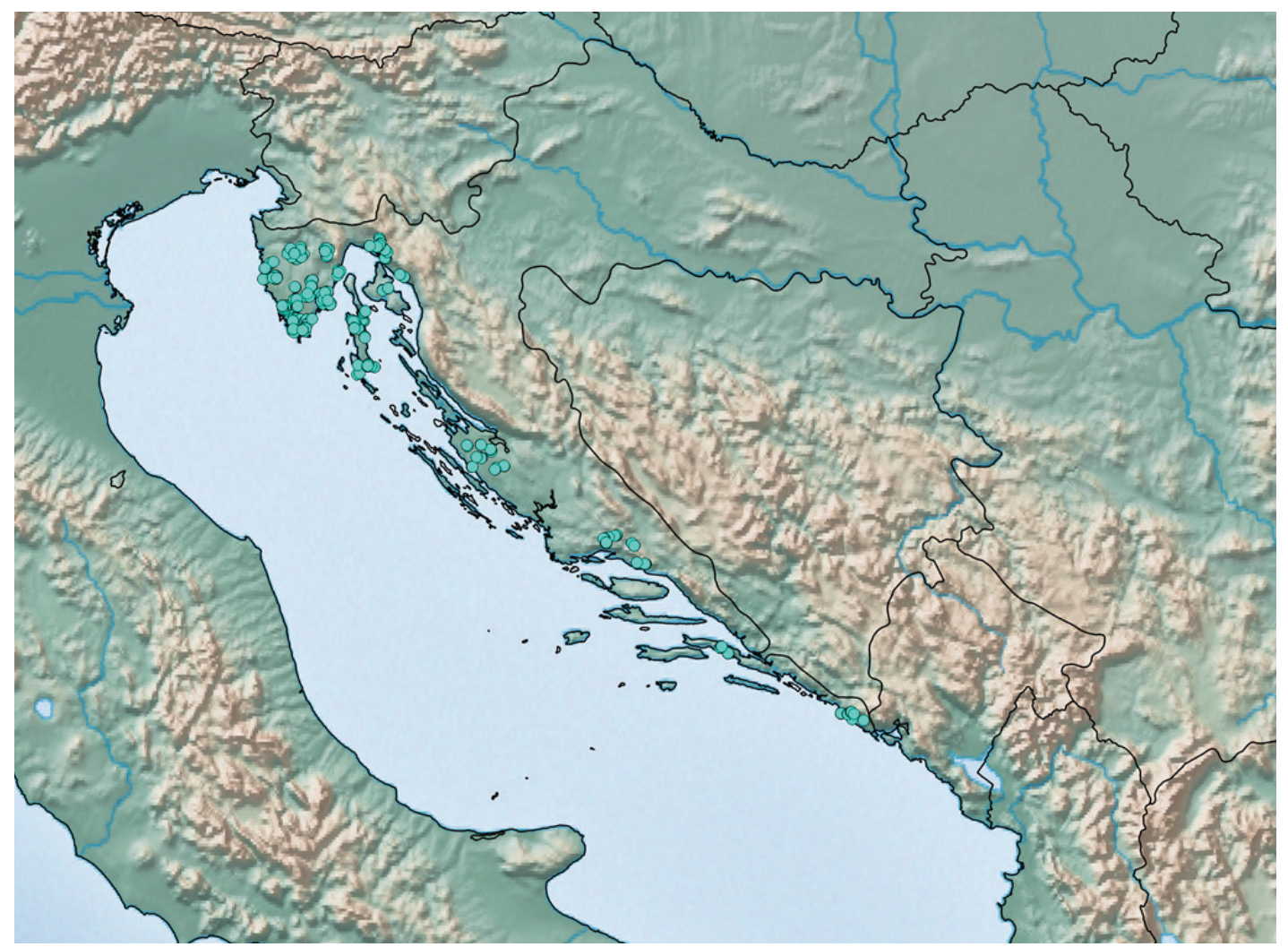

FIGURE 4. Location of sample plots.

\section{Calculation of Site Productivity, Volume Growth Percen- tage and Height of Mean Basal Area Tree}

Site productivity of the forest stand is by definition the production of the forest stand in a certain period of time (e.g. 50 or 100 years) [9], which includes information on the achieved tree height, development of tree height over time, as well as diameter growth and radial increment. Given that the only available information was the age of trees and radial increments for each year, the definition had to be slightly modified and it was decided that the development of cumulative increment at average tree age of 40 years will be studied. The decision to calculate site productivity at the average tree age of 40 years is based on preliminary analysis of the age of cored trees. By setting age higher than 40 years, too many plots would be lost. In case of 40 year-old trees only $9 \%$ (8 out of 92 plots) of plots were lost for QUIL and $6 \%$ (18 out of 285 plots) for QUPU. Plots with trees younger than 40 years were simply not suitable for the calculation of the site productivity.

After that, cumulative value of the radial increment at 40 years was taken and this data was entered into $k$-means clustering in R [17] with request to form 3 groups for QUPU and 2 groups for QUIL. The number of groups per species was based on the range of cumulative radial increment in a given year. For QUPU this range was very wide, while for QUIL it was modestly narrow. A larger number of groups were tested, but due to smaller number of samples overlapping of site indices was bigger. This amount of selected sites showed the best discrimination with minor overlapping of data between sites.

To establish site index classes 1-3 for QUPU and 1-2 for QUIL we (1) allocated the cluster number to each location separately for two analysed tree species, and (2) calculated Prodan's growth function for each productivity group and tree species. For the latter, the NLS function in the R statistical environment was used [17].

By doing this normal (average) tree could be recreated, which was then used for the calculation of the transition time from one DBH class to another, which is the main input in volume growth percentage by [18].

Also, for easier determination of site indices in the field, relevant height curves were calculated (Mihajlov exponential equation [5]) with measured height and assigned site indices.

\section{RESULTS}

\section{Age Structure on Studied Plots}

Age structure of investigated trees is shown in Table 2 and Figure 5. 


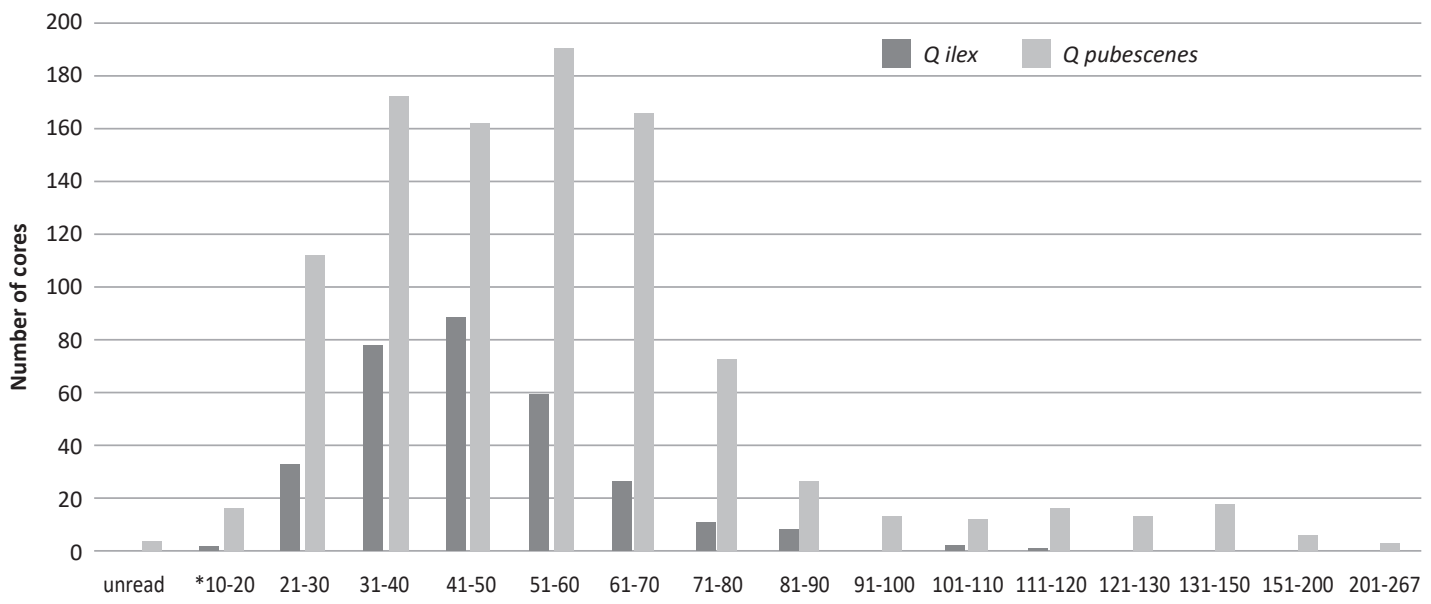

Age of cores

FIGURE 5. Cores grouped by age classes.

TABLE 2. Trees grouped in age classes.

\begin{tabular}{|c|c|c|c|c|c|c|c|c|c|c|c|c|c|c|c|c|c|}
\hline \multirow[b]{2}{*}{ Species } & \multirow[b]{2}{*}{ Unread } & \multicolumn{15}{|c|}{ Age classes (years) } & \multirow[b]{2}{*}{ Total } \\
\hline & & $\begin{array}{l}\text { 오 } \\
\text { ò }\end{array}$ & 并 & $\underset{m}{\stackrel{q}{d}}$ & $\begin{array}{l}\text { 吊 } \\
\stackrel{-}{y}\end{array}$ & $\begin{array}{l}\text { ¿ } \\
\text { in } \\
\text { in }\end{array}$ & $\underset{1}{\stackrel{1}{1}}$ & $\begin{array}{l}\stackrel{\infty}{0} \\
\stackrel{1}{\wedge} \\
\end{array}$ & 冬 & $\begin{array}{l}8 \\
\text { - } \\
\text { İ }\end{array}$ & 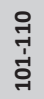 & $\begin{array}{l}\stackrel{9}{7} \\
\underset{-}{\mid}\end{array}$ & 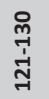 & 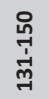 & 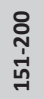 & 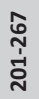 & \\
\hline $\begin{array}{l}\text { Q. pubescens } \\
\text { (QUPU) }\end{array}$ & & 2 & 32 & 77 & 88 & 59 & 26 & 10 & 8 & & 1 & 1 & & & & & 304 \\
\hline $\begin{array}{l}\text { Q. ilex } \\
\text { (QUIL) }\end{array}$ & 3 & 16 & 112 & 173 & 162 & 190 & 165 & 73 & 26 & 12 & 12 & 16 & 13 & 17 & 5 & 3 & 998 \\
\hline Total & 3 & 18 & 144 & 250 & 250 & 249 & 191 & 83 & 34 & 12 & 13 & 17 & 13 & 17 & 5 & 3 & 1302 \\
\hline
\end{tabular}

Since some cores (61) are not cored to the centre due to expressed peculiarity of investigated trees, those cores are not taken into account in further analysis.

\section{Site Index for Quercus pubescens and Quercus ilex}

To establish the site index, it was initially necessary to find differences between the studied plots. The most appropriate method for this was the clustering method by using annual increments on each plot. Therefore, $k$-means clustering was used with request to form 3 groups for QUPU and 2 groups for QUIL.

In the QUPU group 3 classes were identified - mean basal trees on the sites with the highest site index for QUPU achieved diameter of approx. $184 \mathrm{~mm}$, while trees on the sites with the lowest site index for QUPU achieved diameter of only $87 \mathrm{~mm}$ at the age of 40 . The diameters with the highest site index in QUPU group are more than 2 times bigger than the diameters in LOW QUPU group (Table 3).

Sites with predominantly QUIL trees showed smaller growth as compared to sites with predominantly QUPU trees. Therefore, sites with QUIL were split into two groups - those with high and those with low site index. In the HIGH group QUIL trees achieved diameter of about $120 \mathrm{~mm}$ at the age of 40 , while in the LOW group they achieved only $88 \mathrm{~mm}$ at the age of 40 .

Based on the cluster analysis and defined groups, growth curve for each of the site index classes was calculated. Prodan's function was used to express the relationship between age and growth (Equation 1). Prodan's function belongs to a group of so-called s-functions and it describes the relationship between growth and tree age particularly well.

$$
y=\frac{t^{2}}{a+b t+c^{2}}
$$
index.

In Table 6 field data are grouped by investigated site 
TABLE 3. Site productivity classes at the age of 40 for both tree species as calculated with the k-means clustering method

\begin{tabular}{|c|c|c|c|}
\hline Species & Site productivity class & $\begin{array}{l}\text { Average value of the cumulative 2-sided radial growth } \\
\qquad(\mathrm{mm})\end{array}$ & Site productivity description \\
\hline \multirow[t]{3}{*}{ Quercus pubescens } & 1 & 184.92 & High \\
\hline & 2 & 129.06 & Medium \\
\hline & 3 & 87.58 & Low \\
\hline \multirow[t]{2}{*}{ Quercus ilex } & 1 & 119.12 & High \\
\hline & 2 & 88.32 & Low \\
\hline
\end{tabular}

TABLE 4. Coefficients of Prodan's growth function for Quercus pubescens.

\begin{tabular}{cccc}
\hline Site index & a & b & c \\
\hline High & 0.27505442 & 0.24795814 & 0.00461414 \\
Medium & -0.300015346 & 0.465903921 & 0.003865383 \\
Low & -0.559702284 & 0.735878702 & 0.004597677 \\
\hline
\end{tabular}

TABLE 5. Coefficients of Prodan's growth function for Quercus ilex.

\begin{tabular}{cccc}
\hline Site index & a & b & c \\
\hline High & 0.605188232 & 0.427293554 & 0.005386264 \\
Low & 0.559884275 & 0.517723183 & 0.007820995 \\
\hline
\end{tabular}

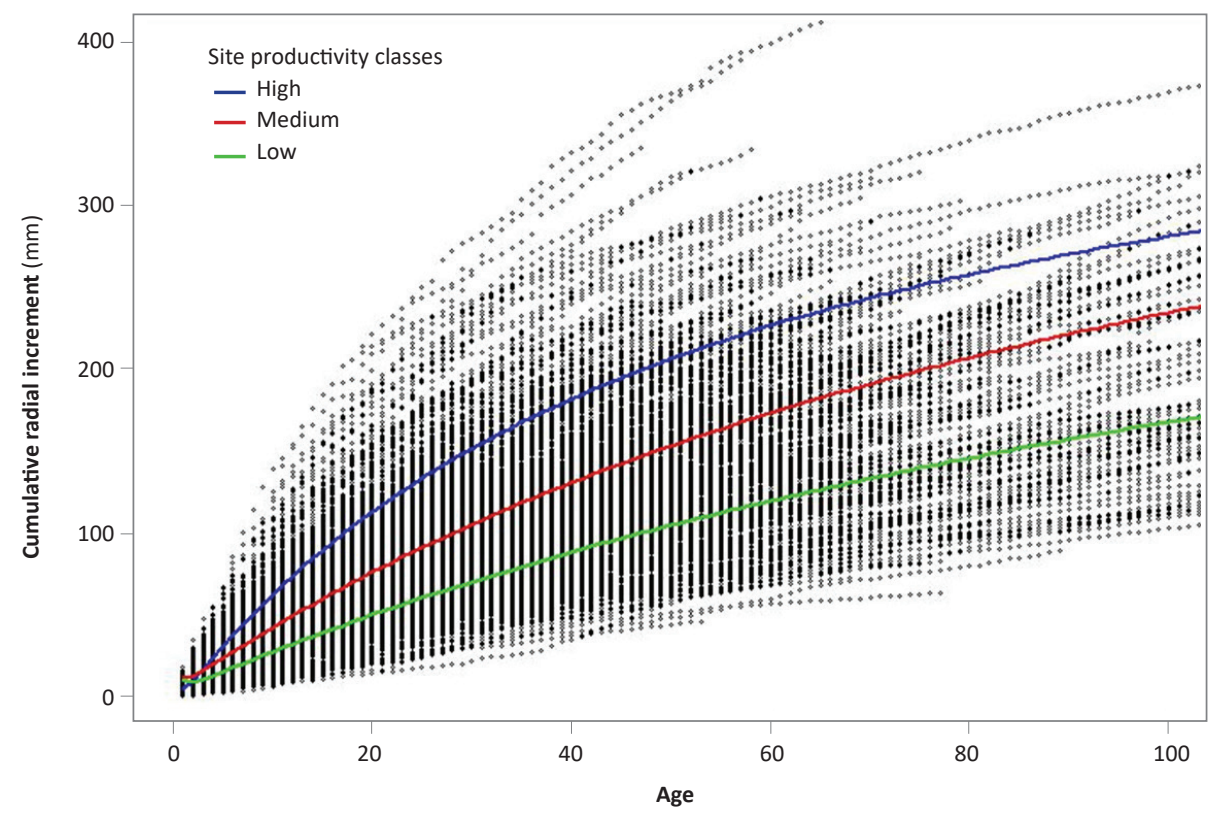

FIGURE 6. Site productivity classes with Prodan's curves embedded for Quercus pubescens. Differences in site indices are visible. Dots represent each analyzed tree-ring in data pool. 


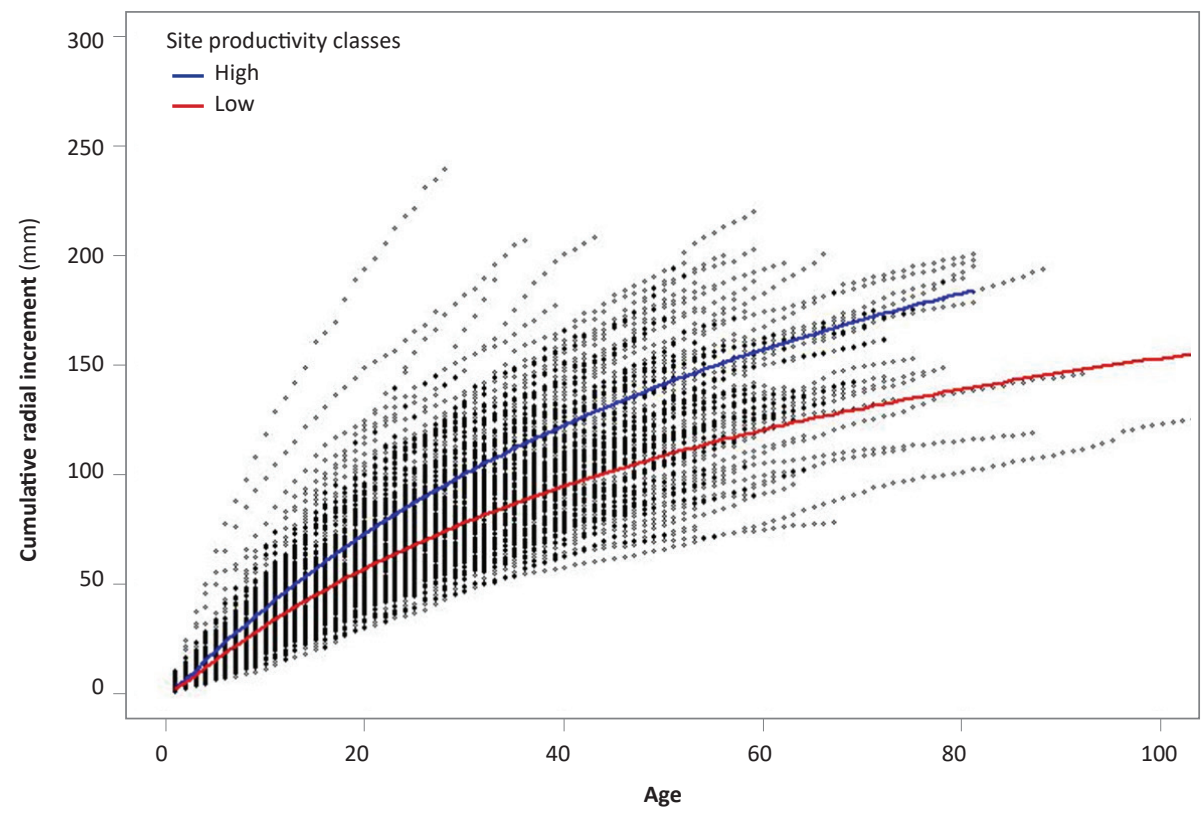

FIGURE 7. Site index classes with Prodan's curves embedded for Quercus ilex. Dots represent each analyzed tree-ring in data pool.

TABLE 6. Field data grouped by assigned site index.

\begin{tabular}{|c|c|c|c|c|c|c|c|c|}
\hline Species & Site index & $\begin{array}{l}\text { No. of } \\
\text { data }\end{array}$ & $\begin{array}{l}\text { Average age } \\
\text { (years) }\end{array}$ & $\begin{array}{l}\text { Average DBH } \\
(\mathrm{cm})\end{array}$ & $\begin{array}{c}\text { Average tree } \\
\text { height }(m)\end{array}$ & $\begin{array}{c}\text { Max age } \\
\text { (years) }\end{array}$ & $\begin{array}{l}\text { Max DBH } \\
(\mathrm{cm})\end{array}$ & $\begin{array}{c}\text { Max tree } \\
\text { height }(\mathrm{m})\end{array}$ \\
\hline \multirow{3}{*}{ Q. ilex } & High & 136 & 43.89 & 15.55 & 9.87 & 81 & 27.90 & 14.30 \\
\hline & Low & 157 & 48.08 & 13.71 & 9.25 & 105 & 25.85 & 17.10 \\
\hline & Total & 293 & 46.14 & 14.56 & 9.54 & 105 & 27.90 & 17.10 \\
\hline \multirow{4}{*}{ Q. pubescens } & High & 174 & 50.73 & 23.31 & 13.29 & 134 & 44.35 & 22.30 \\
\hline & Medium & 411 & 53.14 & 18.86 & 11.75 & 149 & 42.85 & 24.40 \\
\hline & Low & 363 & 62.72 & 15.63 & 9.22 & 267 & 42.25 & 16.70 \\
\hline & Total & 948 & 56.37 & 18.43 & 11.06 & 267 & 44.35 & 24.40 \\
\hline Total & & 1241 & 53.95 & 17.51 & 10.70 & 267 & 44.35 & 24.40 \\
\hline
\end{tabular}

\section{Volume Growth Percentage}

Based on the previous results, transition time from one $\mathrm{DBH}$ to another for average basal area tree by site index was calculated. This transition time was then used to calculate volume growth percentage by Klepac (Equation 2).

$$
p=\frac{1000}{D B H-5} * \frac{1}{T d}
$$

where $\mathrm{p}$ is volume growth percentage, $\mathrm{DBH}$ is diameter at breast height, and Td is transition time.
For easier field site index determination, height curves based on field data for each site index were also calculated using the Mihajlov's height equation (Equation 3).

$$
\mathrm{h}=1.3+b_{0} *\left(\mathrm{e}^{\mathrm{b}_{1} / \mathrm{DBH}}\right)
$$

where $h$ is tree height, $b_{0}$ and $b_{1}$ are parameters and DBH is diameter at breast height.

Volume growth percentages and heights from height curves for each tree species and site index are shown in Table 7. 
TABLE 7. Volume growth percentages and height by tree species and site index.

\begin{tabular}{|c|c|c|c|c|c|c|c|c|c|}
\hline \multirow{2}{*}{ Species } & \multirow{2}{*}{ Site index } & \multirow{2}{*}{ Parameter } & \multicolumn{7}{|c|}{ DBH of mean basal area tree $(\mathrm{cm})$} \\
\hline & & & 12.5 & 17.5 & 22.5 & 27.5 & 32.5 & 37.5 & 42.5 \\
\hline \multirow{6}{*}{ Q. pubescens } & \multirow{2}{*}{ High } & Height (m) & 7.4 & 10.0 & 11.9 & 13.3 & 14.4 & 15.2 & 15.9 \\
\hline & & Growth (\%) & 9.20 & 3.70 & 1.62 & 0.66 & 0.20 & 0.01 & \\
\hline & \multirow{2}{*}{ Medium } & Height (m) & 8.1 & 10.2 & 11.6 & 12.7 & 13.4 & 14.0 & 14.5 \\
\hline & & Growth (\%) & 5.72 & 2.57 & 1.30 & 0.67 & 0.32 & 0.13 & 0.03 \\
\hline & \multirow{2}{*}{ Low } & Height (m) & 6.7 & 8.8 & 10.3 & 11.4 & 12.2 & 12.8 & 13.3 \\
\hline & & Growth (\%) & 3.09 & 1.26 & 0.55 & 0.22 & 0.07 & & \\
\hline \multirow{4}{*}{ Q. ilex } & \multirow{2}{*}{ High } & Height (m) & 7.7 & 9.2 & 10.2 & 10.8 & 11.4 & 11.7 & 12.0 \\
\hline & & Growth (\%) & 4.37 & 1.56 & 0.55 & 0.13 & 0.01 & & \\
\hline & \multirow{2}{*}{ Low } & Height (m) & 7.6 & 9.1 & 10.1 & 10.8 & 11.3 & 11.6 & 12.0 \\
\hline & & Growth (\%) & 1.66 & 0.23 & 0.01 & & & & \\
\hline
\end{tabular}

\section{DISCUSSION}

For the first time in Croatia, systematic and controlled data on the growth (and age) of uneven-aged privately owned forests in the Croatian Mediterranean and subMediterranean area have been collected. Accordingly, the objects of the study were forests of holm oak or downy oak, which cover almost half of the forested area, in various forms, along the Croatian coastline (i.e. approximately 400,000 ha).

Based on the data collected in the field, three different site indices for downy oak and two site indices for holm oak were determined. Also, the volume growth percentage for each site index and species were determined. In addition, height curves were created for easier field site index determination.

From the measured data (Table 6) and equalized heights (Table 7), it can be noticed that the difference between the first and the second site index for holm oak is almost nonexisting, while the difference in the mean diameters and volume growth percentages is significant. This confirms the justification for using the diameter growth and radial increment as a distinctive feature when determining site index in this type of forests.

As mentioned, studies on holm oak are sparse and not comparable to this one. The only comparable results [7] are shown in Table 8. It can be concluded that trees at the sites from this study are more than a half of size of the holm oaks from the previous study. This can be expected, since in the previous study the growth of holm oaks in agroforestry system with low tree density was studied, while in the present study only mean basal area trees in unmanaged, high tree density stands were encompassed.
Other comparable data are mean ring widths obtained from chronologies. In the study of Gea-Izquierdo et al. [8] it is reported that mean ring width on different sites amounts to $1.437 \mathrm{~mm}$ and $2.347 \mathrm{~mm}$ (respectively), while in this case mean ring width is $1.4257 \mathrm{~mm}$ on lower productivity sites and $1.7771 \mathrm{~mm}$ on higher productivity site. This clearly shows that sites for holm oak in Croatia are of lesser quality than in the Iberian Peninsula.

Downy oak has been studied more than holm oak, but not in comparable manner to this research. Rohner et al. [17] investigated growth dependence on environmental variables (slope, elevation, etc.), for $Q$. petrea, Q. robur and $Q$. pubescens together without any differentiation on the species level.

Pranjić and Lukić showed [14] showed the average radial growth rate of approximately $2 \mathrm{~mm}$ and $1.1 \mathrm{~mm}$ for two sites in Istria for 40 years long period. This is completely in accordance with our investigation and the determined average ring width on the lowest $(0.125 \mathrm{~mm})$ and the highest quality sites $(0.230 \mathrm{~mm})$ throughout Croatia.

Comparing the mean ring width reported by Kunstler et al. [11] $(0.228 \mathrm{~mm})$, the highest productivity site in this research has similar ring width, but on the lowest productivity site average ring widths of trees were almost half of that size $(0.125 \mathrm{~mm})$.

Regarding the reported average ring width in southern France [18] (1.0 mm for wet sites and $0.71 \mathrm{~mm}$ for dry sites), in this study all trees on the determined sites have wider average tree ring width.

Low measured tree heights as well as low modeled height with low percentage of volume increment in higher DBH classes clearly show the effect of harsh conditions on the life and development of these stands. These results are

TABLE 8. Comparison of holm oak (Q. ilex) results.

\begin{tabular}{|c|c|c|c|}
\hline \multirow{2}{*}{ Age } & \multicolumn{3}{|c|}{$\mathrm{DBH}(\mathrm{cm})$} \\
\hline & Low density & High density & Gea-Izquierdo et al. [7] \\
\hline 30 & 7.8 & 9.9 & 15 \\
\hline 60 & 12.0 & 15.8 & 27 \\
\hline 90 & 14.7 & 19.6 & 34 \\
\hline
\end{tabular}


evidence that biological and genetic potential had an impact when these trees were young and that they were supported by a certain amount of nutrients from these shallow soils. Furthermore, it can be concluded that external factors quickly affected the growth and development of these trees (and stands) negatively, as well as that these soils cannot support the needs of older and/or bigger trees.

These results could find their application during operational forest management and forest exploitation by enabling more accurate determination of the production strength of the explored stands. They can also help during the development of the NIR (National Inventory of Greenhouse Gases), since these results could be applied throughout the length of the Croatian coast.

\section{CONCLUSIONS}

For the first time in Croatia, systematic and controlled data on the growth (and age) of uneven-aged privately owned forests in the Croatian Mediterranean and subMediterranean area were collected. Based on the data collected in the field, three different site indices for downy oak and two for holm oak were determined. These results could find their application during operational forest management and forest exploitation by enabling more accurate determination of the production strength of the explored stands.

\section{Acknowledgments}

This research is co-financed by the Croatian Ministry of Agriculture with compensation funds from using forest eco-services (Croatian OKFŠ fund). Attitudes (or opinions) expressed here are not necessarily the attitudes (opinions) of the Ministry of Agriculture. We would also like to thank Extension Services for data disposition and all private forest owners that agreed to participate in this research. We extend our gratitude to the reviewers, whose comments and recommendations helped make us this manuscript better.

\section{REFERENCES}

1. AREND M, KUSTER T, GUNTHARDT-GEORG MS, DOBBERTIN M 2011 Provenance-specific growth responses to drought and air warming in tree European oak species (Quercus robus, Q. petrea and Q. pubescens). Tree Physiol 31 (3): 8997. DOI: https://doi.org/10.1093/treephys/tpr004

2. BERTA A, KUŠAN V, KRIŽAN J, STOJSAVLJEVIĆ D, HATIĆ D 2017 Estate characteristics of private-owned forests in Croatia according to regions. Šumar List 141 (1-2): 57-65. DOI: https://doi.org/10.31298/sl.141.1-2.6

3. CAMPELO F, GUTIERREZ E, RIBAS M, NABAIS C, FREITAS H 2007 Relationships between climate and double rings in Quercus ilex from northeast Spain. Can J For Res 37 (10): 1915-1923. DOI: https://doi.org/10.1139/X07-050

4. CHERUBINI P, GARTNER BL, TOGNETTI R, BRAKER OU, SCHOCH W, INNES JL 2003 Identification, measurement and interpretation of tree rings in woody species from mediterranean climates. Biol Rev 78 (1): 119-148. DOI: https://doi.org/10.1017/S1464793102006000

5. ČAVLOVIĆ J 2004: Unapređenje stanja i gospodarenja privatnim šumama na području Zagrebačke županije. Scientific report, University of Zagreb, Faculty of Forestry, Zagreb, Croatia (in Croatian)

6. EILMAN B, WEBER P, TOGNETTI R, ECKSTEIN D 2006 Growth reaction of Pinus syilvestris L. and Quercus pubescens Willd. To drought years at xeric site in Valais, Switzerland. Dendrochronologia 23 (3) :121-132. DOI: Https://doi. org/10.1016/i.dendro.2005.10.002

7. GEA-IZQUIERDO G, CANELLAS I, MONTERO G 2008 Site index in agroforestry systems: age-dependent and ageindependent dynamic diameter growth models for Quercus ilex in Iberian open oak woodlands. Can J For Res 38: 101-113. DOI: https://doi.org/10.1139/X07-142

8. GEA-IZQUIERDO G, MARTÍN-BENITO M, CHERUBINI P, CAÑELLAS I 2009 Climate-growth variability in Quercus ilex L. west Iberian open woodlands of different stand density. Ann For Sci 66 (8): 802. DOI: https://doi.org/10.1051/ forest/2009080
9. GRISSINO-MAYER HD 2001 Evaluating crossdating accuracy: A manual and tutorial for the computer program COFECHA. Tree-Ring Res 57 (2): 205-221

10. KLEPAC D 1954 Tablice postotka prirasta. Šumar List 78 (910): $454-485$

11. KUNSTLER G, CURT T, BOUCHAUD T, LEPART J 2005 Growth, mortality and morphological response of Euroean beach and downy oak along a light gradient in sub-Mediterranean forest. Can J For Res 35 (7): 1657-1668. DOI: https://doi. org/10.1139/x05-097

12. NABAIS C, FREITAS H, HAGEMEYER J 1998-1999 Tree rings to climate relationships of Quercus ilex L. in NE-Portugal. Dendrochronologia 16-17: 37-44

13. PRANJIĆ A 1979 Standard height curves and single-entry tables for the English oak (Quercus robur). Šumar List 103 (7-8): 349-355 (in Croatian)

14. PRANJIĆ A, LUKIĆ N 1990 Razvoj stabala crnog bora i hrasta medunca istarskog područja. Glasnik za šumske pokuse 26 : 433-466 (in Croatian)

15. R-CORE-TEAM 2013 R: A language and environment for statistical computing. R Foundation for Statistical Computing, Vienna, Austria

16. RODA F, RETANA J, GRACIA CA, BELLOT J 1999 Ecology of Mediterranean evergreen oak forests. Springer-Verlag Berlin Heidelberg, Berlin, Germany, 377 p. DOI: https://doi. org/10.1007/978-3-642-58618-7

17. ROHNER B, BUGMANN H, BIGLER C 2013 Estimating the age-diameter relationship of oak species in Switzerland using non-linear mixed effects models. Eur J Forest Res 132 (5-6): 751-764. DOI: https://doi.org/10.1007/s10342-0130710-5

18. SASS-KLAASSEN U, CHOWDHURY Q, STERCK FJ, ZWEIFEL R 2006 Effects of water availability on the growth and tree morphology of Quercus pubescens Willd. and Pinus sylvestris L. in the Valais, Switzerland. In: TRACE- Tree Rings in Archeology, Climatology and Ecology, Vol. 5 Proceeding of the DENDROSYMPOSIUM, 20-22 April 2006. Tervuren, Belgium, pp 206-217 
19. SKOVSGAARD JP, VANCLAY JK 2008 Forest site productivity: a review of the evolution of dendrometric concepts for even-aged stands. Forestry 81 (1): 13-31. DOI: https://doi. org/10.1093/forestry/cpm041
20. STOKES MA, SMILEY TL 1968 An Introduction to tree-ring dating. The University of Arizona Press, Tucson, USA

21. ZHANG SH, ROMANE F 1991 Variations de la croissance radiale de Quercus ilex L. en fonction du climat. Ann For Sci 48 (2): 225-234. DOI: https://doi.org/10.1051/ forest:19910209 